\author{
Krystian RYŚ \\ Karolina DYRLA-MULARCZYK ${ }^{2}$
}

\title{
PSYCHOLOGICZNE I PRAWNE ASPEKTY MOBBINGU W MIEJSCU PRACY
}

\begin{abstract}
Przemoc w miejscu pracy pojawia się z coraz większą a zarazem niepokojącą częstotliwością. Mobbing traktowany jest jako przykład patologii obserwowanej w organizacji. Stąd konieczność spojrzenia na mobbing w sposób wieloaspektowy. Celem artykułu jest przybliżenie psychologicznej natury zjawiska mobbingu, a także wskazanie na mobbing w kontekście polskiego prawa pracy. W artykule zwrócono uwagę na dwie przestrzenie, w jakich należy przyjrzeć się przemocy w organizacji. Pierwsza część artykułu poświęcona jest aspektom związanym z psychologią zdrowia i psychologią organizacji. Druga część artykułu poświęcona jest przestrzeni prawa pracy. W pierwszej części artykułu skupiono się na psychologicznych aspektach zjawiska mobbingu. Na początku została przybliżona definicja mobbingu, wymieniono także przykłady zachowań przemocowych obserwowanych w środowisku organizacyjnym. Scharakteryzowano także ofiarę mobbingu i mobbera. Dalej jest miejsce na omówienie mobbingu jako wieloetapowego procesu. Pierwszą część artykułu zamykają konsekwencje mobbingu, jakie dotykają nie tylko ofiarę przemocy, ale także środowisko organizacyjne. Druga część artykułu została poświęcona aspektom prawnym zjawiska mobbingu w miejscu pracy. Przywołano definicję mobbingu obowiązującą w polskim kodeksie pracy. Ponadto wskazano także na obowiązki pracodawcy, jakie ciążą na nim względem ofiar doświadczających przemocy w miejscy pracy. W artykule znalazło się także miejsce na przykłady działań prewencyjnych związanych z profilaktyką zjawiska mobbingu w organizacji. Artykuł zamykają prawne konsekwencje mobbingu.
\end{abstract}

Słowa kluczowe: patologia organizacyjna, przemoc w organizacji, polskie prawo pracy, procedury antymobbingowe.

\section{WPROWADZENIE}

Skala zjawiska mobbingu w miejscu pracy jest niepokojąca. Według danych zgromadzonych przez Centrum Badania Opinii Społecznej w 2014 aż 17\% pracowników przyznaje

\footnotetext{
${ }^{1}$ Mgr Krystian Ryś, Uniwersytet Opolski, Wydział Prawa i Administracji, pl. Kopernika 11 a, 45-040 Opole; autor korespondencyjny; e-mail: krys@ uni.opole.pl.

Krystian Ryś,M.A., University of Opole, Faculty of Law and Administration, Copernicus Square 11, 45-040 Opole; corresponding author; e-mail: krys@uni.opole.pl.

2 Dr Karolina Dyrla-Mularczyk, Politechnika Poznańska, Wydział Inżynierii Zarządzania, ul. Strzelecka 11, 60-965 Poznań; e-mail: carolinemularczyk@gmail.com.

Karolina Dyrla-Mularczyk, PhD, Poznan University of Technology, Faculty of Management Engineering, Strzelecka 11, 60-965 Poznan; e-mail: carolinemularczyk@gmail.com.
} 
się do doświadczania przemocy ze strony swoich pracodawców i przełożonych ${ }^{3}$. Mobbing niesie ze sobą dotkliwe konsekwencje, które dotykają nie tylko ofiary przemocy, ale wpływają także na funkcjonowanie i pracę zespołów w organizacji. Na zjawisko mobbingu należy spojrzeć z kilku perspektyw - prawa pracy, zdrowia psychicznego, psychologii organizacji.

\section{MOBBING A PSYCHOLOGIA}

Termin mobbingu do współczesnej psychologii wprowadził Peter Paul Heinemann. Użył go w kontekście obserwowanej w środowisku szkolnym przemocy dziecięcej. Powszechnie przyjęta definicja mobbingu Leymanna mówi, że mobbing ma charakter wrogiej i nieetycznej komunikacji międzyludzkiej, gdzie jedna ze stron doprowadza swoim zachowaniem drugą stronę do strat i cierpienia w wymiarach zdrowia fizycznego i psychicznego ${ }^{4}$. Nieco wcześniej termin mobbing pojawił się w pracach zoologa Karla Lorenza. Mobbing oznaczał zachowania obserwowanych w środowisku zwierząt, które polegały na ataku przez grupę zwierząt osobnika traktowanego jako intruza. Dziś powszechnie rozumiemy mobbing jako każde niewłaściwe zachowanie, które przez swoją powtarzalność i systematyczność narusza godność innej osoby, uderza w jej zdrowie psychiczne i fizyczne, prowadząc do utraty zatrudnienia lub pogorszenia atmosfery w miejscu pracy ${ }^{5}$. Prześladowanie ma charakter uporczywy (przynajmniej raz na tydzień dochodzi do sytuacji mobbingowej) i długotrwały (prześladowanie trwa od ponad pół roku). Osoby szykanowane i prześladowane w miejscu pracy są odsuwane od awansu, podwyżki, nie są angażowane w zadania służące rozwojowi zawodowemu. Niejednokrotnie działania mobbingowe mają podłoże dyskryminacji ze względu na płeć, wiek, staż pracy, pochodzenie.

Współcześnie rozumiany mobbing w organizacji przybiera postać demonstrowania wrogiego nastawienia i nękania pracownika poprzez szereg działań, takich jak: utrudnianie wykonywania pracy, izolację i wykluczenie, bezzasadne oskarżenia, złośliwe opinie i zachowania, nieprzekazywanie informacji związanych $\mathrm{z}$ wykonywaniem obowiązków ${ }^{6}$. Szczegółowej klasyfikacji zachowań mobbingowych dokonał Leymann, dzieląc czynności mobbera na działania ${ }^{7}$ :

- utrudniające komunikację (m.in. przerywanie, groźby, akty agresji werbalnej, ograniczenie lub uniemożliwienie ofierze wypowiadania się etc.);

- wpływające negatywnie na kontakty społeczne (m.in. izolacja i ignorowanie ofiary);

- naruszające wizerunek ofiary (m.in. plotkowanie, żartowanie, wyśmiewanie, szykanowanie ofiary);

- uderzające w pozycję zawodową ofiary (m.in. kwestionowanie kompetencji ofiary, odbieranie jej zadań, przydzielanie zadań niemożliwych do realizacji);

- uderzające w zdrowie ofiary (m.in. znęcanie się fizyczne, molestowanie seksualne).

${ }^{3}$ Centrum Badania Opinii Społecznej, Szykany i mobbing w miejscu pracy - Polska lipiec 2014, 2014, http://www.rynekpracy.pl/monitor_rynku_pracy_1.php/wpis.289 (dostęp: 26.04.2018 r.).

${ }^{4}$ H. Leymann, The content and development of mobbing at work, „European Journal of Work and Organizational Psychology" 1996, 5,2, s. 165.

${ }_{5}^{5}$ M.F. Hirigoyen, Molestowanie w pracy, tłum. M. Żerańska, Poznań 2003.

6 A. Bechowska-Gebhardt, T. Stalewski, Mobbing: patologia zarzadzania personelem, Warszawa 2004.

${ }^{7}$ H. Leyman, The content ..., s. 170-171. 
Obecnie repertuar powyższych zachowań mógł się znacznie rozszerzyć, co w opinii autorów artykułu, wiąże się z postępującymi zmianami w organizacjach. Autorzy badań CBOS wskazują na najczęściej pojawiające się w wypowiedziach mobbingowanych respondentów działania takie jak, m.in.:

- bezpodstawne nakładanie kar na pracowników,

- okazywanie niechęci i urazy,

- powierzanie obowiązków powyżej kompetencji pracownika,

- odmawianie urlopu.

Mobbing może rozwinąć się w miejscu pracy dzięki zaistnieniu pewnych czynników sytuacyjnych, do których należą

- sztywne struktury organizacji;

- chaos i monotonia w miejscu pracy;

- brak jasności w przydzielaniu zadań pracownikom;

- niejasny system oceny, wynagradzania, awansu i brak sprecyzowanej ścieżki kariery;

- słaba lub nadmierna kontrola;

- niejasna hierarchia w organizacji;

- chęć eliminacji konkurencji;

- poczucie bezkarności;

- wysoka pozycja społeczna i/lub zawodowa mobbera.

Mobbingowi sprzyja także sytuacja bezrobocia i idąca za nią obawa przed utratą posady. Ponadto procesy związane ze zmianami w organizacji, mogą wywołać niepewność wśród członków organizacji, co również sprzyja mobbingowi.

Podobnie jak w wypadku każdej sytuacji przemocowej, tak i w wypadku mobbingu można wyróżnić pewne cechy ofiary mobbera9 ${ }^{9}$. Ofiarami mobbingu stają się osoby, których kompetencje stanowią zagrożenie dla mniej zdolnych jednostek (a więc osoby pracowite, ambitne i osiągające wysokie wyniki w pracy). Na mobbing narażone są osoby, które charakteryzuje pracoholizm i duże zaangażowanie $\mathrm{w}$ wykonywane obowiązki ${ }^{10}$. Ponadto wśród ofiar mobbingu w organizacji często występują osoby, doświadczające problemów w życiu osobistym i osoby nienależące do grup i klik w organizacji (a zarazem pozbawione wsparcia ze strony współpracowników). Mobbera charakteryzują zdolności manipulatorskie, potrafi on dzięki swojej charyzmie zjednać sobie innych członków zespołu, tworząc tym samym koalicję przeciwko ofierze ${ }^{11}$. Agresorami są osoby atrakcyjne i przebojowe, pewne siebie, cieszące się poważaniem i szacunkiem.

Sytuacja mobbingowa przebiega w czterech fazach ${ }^{12}$ :

- Początek sytuacji mobbingowej stanowi konflikt, który pojawia się w miejscu pracy, a mobbing staje się strategią rozwiązania problemu.

\footnotetext{
${ }^{8}$ L. Jabłonowska, Przeciwdziałanie zjawiskom patologicznym w procesie pracy [w:] Zarzadzanie kapitałem ludzkim, red. M. Juchnowicz, Warszawa 2014, s. 443-447.

9 M.F. Hirigoyen, Molestowanie ..., s. 125.

10 A. Bechowska-Gebhardt, T. Stalewski, Mobbing: patologia..., s. 51.

11 Ibidem, s. 16.

${ }^{12}$ H. Leymann, The content..., s. 171-172.
} 
- W kolejnej fazie pojawiają się zachowania stygmatyzacyjne - alienacja ofiary i odcięcie jej od wsparcia innych; pojawiają się zachowania takie jak: obmawianie, poniżanie, szykanowanie ofiary.

- Po przekroczeniu tzw. breaking point (indywidualnej granicy tolerancji zachowań mobbingowych) następuje kolejny etap przejawiający się poprzesz pogarszające się samopoczucie fizyczne i psychiczne ofiary, co wiąże się z częstymi wizytami u lekarza i diagnostyką w kierunku szeregu chorób. Niejednokrotnie ta sytuacja staje się przyczyną jeszcze intensywniejszego szykanowania ofiary.

- Efektem poprzednich faz jest zwolnienie z pracy.

Mobbing odciska się piętnem na zdrowiu psychicznym i fizycznym. Do najczęściej pojawiających się konsekwencji zdrowotnych należą:

- zaburzenia nastroju, zaburzenia lękowe, syndrom stresu pourazowego (PTSD - posttraumatic stress disorder);

- zaburzenia ze strony układu sercowo-naczyniowego, oddechowego czy układu odżywiania;

- chroniczne dolegliwości bólowe;

- zaburzenia snu;

- obniżone poczucie własnych kompetencji i brak wiary we własne siły;

- nieradzenie sobie ze stresem odczuwanym w miejscu pracy może skutkować uzależnieniami.

Mobbing pociąga za sobą także konsekwencje organizacyjne. Ofiara napiętnowania w miejscu pracy rzadziej pojawia się na stanowisku, a poprzez problemy z koncentracją i uwagą może nieefektywnie wykonywać swoje obowiązki. Praca zespołu jest zdezorganizowana przez zwolnienia pracowników. Bycie obserwatorem przemocy może potencjalnie obniżyć morale całego zespołu. Budzący się lęk i obawa przed wygłaszaniem własnych poglądów, mogą tłumić potencjał kreatywny jednostek i sprzyjać postawie konformistycznej.

\section{MOBBING A LITERA PRAWA}

Definicja legalna mobbingu zawarta jest w ustawie z dnia 26 czerwca 1974 r. Kodeks pracy $^{13}$. Zgodnie $\mathrm{z}$ art. $94^{3} \mathrm{k}$.p. mobbing to działania lub zachowania dotyczące pracownika albo skierowane przeciwko pracownikowi, polegające na uporczywym i długotrwałym jego nękaniu lub zastraszaniu oraz wywołujące u niego zaniżoną ocenę przydatności zawodowej. Mogą prowadzić do poniżenia lub ośmieszenia pracownika, a także izolowania lub wyeliminowania go z zespołu współpracowników. Należy zauważyć, że treść definicji przemawia za koniecznością łącznego spełnienia ustawowych przesłanek mobbingu ${ }^{14}$.

Kodeksowa definicja mobbingu opisuje zachowania dotyczące pracownika lub przeciwko niemu skierowane, ale nie wskazuje ona osób, które mogą ich dokonywać. Należy zatem przyjąć, że sprawcą mobbingu może być zarówno pracodawca, jak i osoby zarządzające zakładem pracy w jego imieniu, przełożeni pracownika oraz inni pracownicy. Obowią-

13 Tekst jedn.: Dz.U. z 2016 r. poz. 1666 z późn. zm. (dalej jako: k.p.)

${ }^{14}$ M. Tomaszewska [w:] Kodeks pracy. Komentarz, red. K.W. Baran, Warszawa 2016, s. 691. 
zek stworzenia środowiska pracy wolnego od mobbingu statuuje odpowiedzialność pracodawcy także wtedy, gdy mobberem staje się osoba zatrudniona w ramach innej podstawy niż stosunek pracy ${ }^{15}$.

Ofiarą mobbingu w rozumieniu kodeksu pracy może stać się wyłącznie pracownik. Regulacje prawa pracy nie obejmują swoim zakresem zachowań skierowanych przeciwko osobom wykonującym pracę $w$ ramach zatrudnienia niepracowniczego ${ }^{16}$. Trafnie zwraca się uwagę, że ofiary pozbawione statusu pracownika będą mogły dochodzić swoich roszczeń przed sądem cywilnym w oparciu o regulacje ustawy z dnia 23 kwietnia 1964 r. Kodeks cywilny ${ }^{17}$. Taka konstrukcja prowadzi do swoistego uprzywilejowania pracowników wobec osób świadczących pracę w zatrudnieniu niepracowniczym. Wszak pracownicy także mogą korzystać $\mathrm{z}$ regulacji przewidzianych $\mathrm{w}$ prawie cywilnym poza uprawnieniami wynikającymi z art. $94^{3}$ k.p. Zakres ich ochrony jest zatem szerszy. Wydaje się, że pomimo immamentnych cech stosunku pracy, w praktyce sytuacja faktyczna osób świadczących w przedsiębiorstwie pracę na podstawie umów o pracę oraz umów cywilnoprawnych często będzie zbliżona.

Słowa komentarza wymaga pojęcie pracodawcy. $\mathrm{Z}$ art. $22 \S 1$ k.p. w zw. $\mathrm{z}$ art. 3 k.p. wynika, że pracodawca jest stroną stosunku pracy, a zatem podmiotem, który zatrudnia pracownika. W sferze prawa pracy doniosłe znaczenie ma zarządcza koncepcja pracodawcy. Oznacza ona, że pracodawcą jest jednostka organizacyjna, której kierownictwo legitymuje się mandatem do zarządzania nią i kierowania pracownikami. Nie ma znaczenia, czy ma tytuł majątkowy do zakładu pracy, czy też nie. Model zarządczy zdaje się mieć korzenie w socjalistycznej zasadzie jedności własności państwowej. W wyniku swoistego odejścia od teorii jedności własności państwowej koncepcja podmiotowości zarządczej wewnętrznych jednostek organizacyjnych osób prawnych straciła znaczenie w prawie gospodarczym. Jej ostatni bastion stanowi prawo pracy ${ }^{18}$.

Interesujący jest konkurencyjny model właścicielski pracodawcy. Zgodnie z nim za pracodawcę uznaje się podmiot, który zatrudnia pracowników w oparciu o majątkową (cywilnoprawną) zdolność do dysponowania zakładem pracy. Jest to nader widoczne w odniesieniu do stosunków gospodarczych. W takim ujęciu pracodawcą jest osoba prawna oraz przedsiębiorca niemający osobowości prawnej, lecz będąca jednocześnie samodzielnym podmiotem stosunków majątkowych i gospodarczych ${ }^{19}$.

Możliwa wydaje się teza, że pojęcie pracodawcy mogłoby przynależeć szeroko ujmowanemu prawu zatrudnienia ${ }^{20}$. Warto zauważyć, że głęboka ingerencja państwa w stosunki pracy zarobkowej jest uzasadniona szczególnymi wartościami, z którymi się wiążą (życie i zdrowie, wolność oraz godność człowieka pracującego), oraz ich ogromnym znaczeniem

15 Ibidem, s. 692.

16 J. Semena, Mobbing i przeciwdziałanie temu zjawisku na gruncie Kodeksu pracy, „Kwartalnik Prawo - Społeczeństwo - Ekonomia” 2015, nr 3, s. 63.

17 Tekst jedn.: Dz.U. z 2017 r., poz. 459 ze zm.

18 Z. Hajn, Zbiorowe prawo pracy. Zarys systemu, Warszawa 2013, s. 105-107.

19 Ibidem, s. 107.

${ }^{20}$ Należy zauważyć, że niektórzy autorzy poddają krytyce wprowadzenie nazwy „prawo zatrudnienia”. Uznają to za inicjatywę neoliberalnych ekonomistów. Jednocześnie wskazują na określoną tradycję i aksjologię prawa pracy oraz ,pojemność" prawa pracy (tak: T. Liszcz, Niech prawo pracy pozostanie prawem pracy [w:] Przysztość prawa pracy. Liber Amicorum, red. Z. Hajn, D. Skupień, Łódź 2015, s. 277-280). 
społeczno-gospodarczym ${ }^{21}$. W doktrynie dostrzega się także potrzebę objęcia ochroną osób wykonujących pracę w ramach zatrudnienia niepracowniczego. Standardy międzynarodowe $\mathrm{z}$ zakresu ochrony osób wykonujących pracę wykraczają bowiem poza ramy wąsko ujmowanego stosunku pracy ${ }^{22}$. Stosunki prawne zachodzące pomiędzy pracodawcami a pracownikami mogą mieć różny charakter, w tym także charakter majątkowy. Pojęcie mobbingu mogłoby stanowić zatem termin właściwy dla całego prawa zatrudnienia a nie tylko prawa pracy. W konsekwencji zakres podmiotowy tego pojęcia uległby rozszerzeniu. Wszak osoby wykonujące pracę na podstawie umów cywilnoprawnych także mogą być dotknięte zachowaniami, których znamiona wypełniałyby definicję mobbingu. Wydaje się, że prawo winno być uwarunkowane aktualną sytuacją na rynku pracy oraz odpowiadać potrzebom zarówno społeczeństwa, jak i gospodarki²3.

\section{OBOWIĄZEK PRACODAWCY PRZECIWDZIALANIA MOBBINGOWI}

W literaturze niemieckiej genezę obowiązku pracodawcy przeciwdziałania mobbingowi łączy się z powszechną dbałością o dobro pracownika. Wynika z niego bowiem, że pracodawca winien jest wykazywać troskę o życie, zdrowie i godność osób, które zatrudnia. Powinność ta wyraża się w ochronie pracowników przed niebezpieczeństwem utraty życia lub zdrowia, na które mogą być narażeni w środowisku pracy ${ }^{24}$. Ogólny obowiązek swoistej pieczy nad osobami zatrudnianymi można wiązać z koniecznością ochrony tych ostatnich przed mobbingiem związanym ze świadczeniem pracy.

W zakresie omawianej problematyki kluczowy jest obowiązek nakładany na pracodawcę $\mathrm{w}$ art. $94^{3} \S 1$ k.p. Ustawodawca przed wskazaniem cech mobbingu sygnalizuje, iż to pracodawca jest zobowiązany do przeciwdziałania temu zjawisku. Oznacza to że, na gruncie prawa pracy właśnie na nim spoczywa główna odpowiedzialność za eliminację wszelkich patologicznych zachowań w miejscu pracy. Należy zatem wyprowadzić wniosek, że pracodawca nie zawsze będzie utożsamiany z osobą będącą sprawcą mobbingu ${ }^{25}$. Niezależnie od tego, podmiot zatrudniający pracowników winien jest pamiętać o podstawowych obowiązkach względem nich, do których można zaliczyć zapewnienie bezpiecznych i higienicznych warunków pracy, stosowanie obiektywnych i sprawiedliwych kryteriów oceny podwładnych oraz wpływanie na kształtowanie w zakładzie pracy zasad współżycia społecznego ${ }^{26}$.

Powinności nakładane na pracodawcę mogą mieć zarówno charakter normatywny, jak i umowny. Przy czym, obowiązek zawarty w art. $94^{3} \S 1$ k.p. stanowi przede wszystkim powinność normatywną i ma bezwzględny charakter. Pracodawca nie może zatem zwolnić się z jego wykonywania przez inne świadczenie zastępcze. Wydaje się, że obowiązek

21 Ibidem, s. 280.

${ }^{22}$ Ł. Pisarczyk, Prawo pracy wobec rozwoju zatrudnienia cywilnoprawnego [w:] Przyszłość..., s. 351.

23 Ibidem, s. 362.

${ }^{24}$ G. Schaub, Rechte und Pflichten als Arbeitnehmer, München 2001, s. 309 i n.; G. Wiese, Der Persönlichkeitsschutz des Arbeitsnehmers gegenüber dem Arbeitgeber, "Zeitschrift für Arbeitsrecht" 1971, nr 1, s. 278.

25 M. Bosak, A. Danilewicz, Odpowiedzialność cywilna i karna za mobbing, „Prokuratura i Prawo” 2010, nr 4, s. 103-104.

${ }^{26}$ Ibidem, s. 104. 
przeciwdziałania mobbingowi można uznać za przynależny do grupy podstawowych obowiązków pracodawcy w rozumieniu art. $55 \S 1^{1}$ k.p. Niemniej nie służy on bezpośredniej realizacji podstawowych celów stosunku pracy ${ }^{27}$.

Ustawodawca nie określił treści obowiązku wynikającego z art. $94^{3} \S 1$ k.p., a także nie wskazał sposobów jego realizacji. Za nietrafne można uznać sformułowanie ,pracodawca jest zobowiązany przeciwdziałać mobbingowi". Ten zwrot niejako sugeruje, że chodzi jedynie o przeciwdziałanie mobbingowi między pracownikami, a wykładnia systemowa i funkcjonalna prowadzi do wniosku, że przepis ten należy interpretować szerzej. Prawodawca miał także na względzie ochronę przed działaniami mobbingowymi ze strony pracodawcy ${ }^{28}$. Przywołany obowiązek wiąże się z powinnością zatrudniającego pracowników do zapewnienia takich warunków środowiska pracy, w których nie będą oni narażeni na mobbing. Winna być ona realizowana w sposób niezależny od rodzaju relacji: wertykalnej (pracodawca-pracownik) lub horyzontalnej (pracownik-pracownik).

De lege lata kodeksowy obowiązek przeciwdziałania mobbingowi pozostaje nieskonkretyzowany. W literaturze przedmiotu wskazuje się jednak, że pracodawca ponosi odpowiedzialność za sam brak jego realizacji, a więc za istnienie takich warunków i atmosfery w pracy, które umożliwiają stosowanie mobbingu ${ }^{29}$. Obowiązek przeciwdziałania temu zjawisku, jako objęty treścią stosunku pracy, ma charakter złożony. Składają się bowiem nań: skierowany do pracodawcy zakaz mobbingu, obowiązek wykluczania praktyk mobbingowych podejmowanych przez osoby trzecie względem pracownika oraz zapobiegania jego powstawaniu w środowisku pracy - prewencja antymobbingowa ${ }^{30}$.

W jaki sposób pracodawca powinien realizować swój obowiązek? Powinien on przeciwdziałać zarówno stwierdzonym przypadkom mobbingu, jak i podejmować skuteczne działania prewencyjne. W doktrynie wskazuje się, że prewencja może przejawiać się w postaci odpowiednich szkoleń, rozpowszechniania informacji o niebezpieczeństwie i konsekwencjach mobbingu oraz wprowadzania środków komunikacji z pracownikami poza strukturą bezpośredniego podporządkowania, przy jednoczesnym zapewnieniu anonimowości i niedyskryminacji ${ }^{31}$. Kluczowe znacznie ma wewnętrzna polityka antymobbingowa zakładu pracy. Wydaje się, że jest ona najskuteczniejszą prewencyjną metodą walki z patologicznymi zachowaniami w miejscu pracy ${ }^{32}$. Należy zauważyć, że jeśli procedury antymobbingowe zostaną ujęte $\mathrm{w}$ obowiązującym układzie zbiorowym lub regulaminie pracy, to będą stanowić źródło prawa pracy w rozumieniu art. 9 k.p. ${ }^{33}$ De lege ferenda winno postulować się wprowadzenie obowiązku przyjmowania wewnętrznych postępowań przeciwdziałających mobbingowi. Takie rozwiązanie wyraźnie wzmacniałoby aspekt prewencyjny obowiązku pracodawcy z art. $94^{3} \S 1$ k.p. Interesującym rozwiązaniem, stosowanym w roz-

${ }^{27}$ H. Szewczyk, Mobbing..., s. 149.

28 Ibidem, s. 153.

${ }^{29}$ M. Romer, Mobbing i jego konsekwencje, ,Prawo Pracy” 2005, z. 12, s. 3-4.

30 W. Cieślak, J. Stelina, Definicja mobbingu oraz obowiazek pracodawcy przeciwdziałania temu zjawisku, „Państwo i Prawo” 2004, nr 12, s. 64-75.

31 A. Sobczyk, D. Dörre-Nowak, Przeciwdziatanie mobbingowi, „Monitor Prawa Pracy” 2006, nr 10, s. 527-528.

${ }^{32}$ H. Szewczyk, Zapobieganie mobbingowi oraz zwalczanie jego skutków przez pracodawcę, „Bezpieczeństwo Pracy” 2015, nr 10, s. 13.

${ }_{33}$ M. Chakowski, Wewnętrzna polityka antymobbingowa droga do rozwiazania problemu mobbingu na poziomie zaktadu pracy, „Monitor Prawa Pracy” 2010, nr 12, s. 637. 
winiętych gospodarczo krajach europejskich, jest ustanowienie ,doradcy do spraw prewencji” lub „osoby zaufania”. Ich rolą jest rozwiązywanie problemów mobbingu na poziomie przedsiębiorstwa. Instytucja ta może prowadzić do zwiększenia skuteczności wewnętrznych mechanizmów eliminujących zachowania mobbingowe ${ }^{34}$.

Należy pamiętać, że realizacja obowiązku z art. $94^{3} \S 1$ k.p. powinna obejmować nie tylko działania zapobiegające występowaniu mobbingu, ale także mające na celu pomoc ofierze i eliminację jego stwierdzonych przypadków w środowisku pracy.

\section{PRAWNE KONSEKWENCJE MOBBINGU}

Na gruncie prawa pracy ofiarom mobbingu przysługują określone uprawnienia, które wiążą się z odpowiedzialnością pracodawcy. W art. $94^{3} \S 3$ i 4 k.p. przewidziano dwa rodzaje sankcji mające zastosowanie wobec pracodawcy, który nie przeciwdziałał mobbingowi. Są to zadośćuczynienie pieniężne za doznaną przez pracownika krzywdę, jeżeli mobbing doprowadził do rozstroju zdrowia, oraz odszkodowanie związane z rozwiązaniem umowy o pracę przez pracownika nękanego mobbingiem. Odszkodowanie to nie może być niższe niż minimalne wynagrodzenie za pracę, natomiast jego górna granica nie jest limitowana $^{35}$. Konstrukcja prawna zadośćuczynienia jest wzorowana na art. 444 i 445 kodeksu cywilnego $^{36}$. Niemniej zawiera ona różnice w stosunku do rozwiązań przyjętych w prawie cywilnym. Mobbing jest bowiem kwalifikowanym deliktem prawa pracy, a sankcje przewidziane za jego stosowanie stanowią zdarzenia prawa pracy. Wobec tego, sądy kierują się dorobkiem judykatury cywilistycznej, ale osądzają przede wszystkim na podstawie art. $94^{3}$ k.p. ${ }^{37}$.

„Czynnikiem krytycznym dla wielu przedsiębiorców jest fakt, że zgodnie z obowiązującymi przepisami pracodawca odpowiada za mobbing również w sytuacji, w której nic nie wiedział o występowaniu tego zjawiska na terenie swojego przedsiębiorstwa. Dzieje się tak, ponieważ odpowiada on za całokształt funkcjonowania zakładu pracy i m.in. za kształtowanie w zakładzie pracy zasad współżycia społecznego" 38 . Wydaje się, że pracodawcy najbardziej obawiają się konieczności wypłaty świadczeń pieniężnych z tytułu mobbingu. Niemniej w literaturze często wskazuje się, że pracodawcy postrzegają zagrożenie konsekwencjami mobbingu jako wyłącznie potencjalne ${ }^{39}$. Zakład pracy, w którym dochodzi do mobbingu, powinien liczyć się z poniesieniem realnych kosztów ekonomicznych. W skrajnych przypadkach informacje o stosowaniu mobbingu mogą objąć szersze grono odbiorców, zatem ucierpi także renoma przedsiębiorcy ${ }^{40}$.

Pracownik może dochodzić odpowiedzialności pracodawcy z art. $94^{3}$ k.p. w drodze postępowania sądowego. Niemniej warto pamiętać także o pozasądowych sposobach rozwiązywania sporów związanych z mobbingiem. Należy zliczyć do nich: postępowania przed

\footnotetext{
${ }^{34}$ H. Szewczyk, Zapobieganie..., s. 13.

35 J. Wratny, Kodeks pracy. Komentarz, Warszawa 2016, s. 322.

${ }^{36}$ Ustawa z dnia 23 kwietnia 1964 r. Kodeks cywilny (tekst jedn.: Dz.U. z 2017 r., poz. 459 ze zm.).

${ }^{37}$ M. Tomaszewska [w:] Kodeks..., s. 695.

38 J. Marciniak, Mobbing, dyskryminacja, molestowanie. Przeciwdziałanie w praktyce, Warszawa 2015, s. 105

39 Ibidem, s. 105 i 111.

40 A. Roguska-Kikoła, M. Piwowarska-Reszka, Mobbing i dyskryminacja w stosunkach pracy, Warszawa 2014, s. 43.
} 
komisją pojednawczą, postępowanie przed mediatorem lub zawezwanie do próby ugodowej.

\section{PODSUMOWANIE}

Mobbing to przykład patologii występującej w organizacji, która przez wzgląd na szkodliwe i dotkliwe konsekwencje, powinna być rozpatrywana z kilku perspektyw. Znajomość mechanizmów stojących u podstaw zjawiska przemocy w miejscu pracy może pozwolić na wdrożenie stosownych programów prewencyjnych. Ponadto brak przyzwolenia na mobbing w organizacji jest istotny także ze względu na efektywność pracy zespołów w organizacji.

\section{LITERATURA}

1. Bechowska-Gebhard A., Stalewski T., Mobbing: patologia zarzadzania personelem, Difin, Warszawa 2004.

2. Bosak M., Danilewicz A., Odpowiedzialność cywilna i karna za mobbing, „Prokuratura i Prawo" 2010/4.

3. Chakowski M., Wewnętrzna polityka antymobbingowa droga do rozwiązania problemu mobbingu na poziomie zakładu pracy, „Monitor Prawa Pracy” 2010/12.

4. Cieślak W., Stelina J., Definicja mobbingu oraz obowiazek pracodawcy przeciwdziałania temu zjawisku, „Państwo i Prawo”, 2004/12.

5. Hajn Z., Zbiorowe prawo pracy. Zarys systemu, Wolters Kluwer, Warszawa 2013.

6. Hirigoyen M.F., Molestowanie w pracy, tłum. M. Żerańska, Wydawnictwo W Drodze, Poznań 2003.

7. Leymann H., The content and development of mobbing at work, „European Journal of Work and Organizational Psychology" 5/2 (1996).

8. Liszcz T., Niech prawo pracy pozostanie prawem pracy [w:] Przyszłość prawa pracy, red. Z. Hajn, D. Skupień, Liber Amicorum, WUŁ, Łódź 2015.

9. Pisarczyk Ł., Prawo pracy wobec rozwoju zatrudnienia cywilnoprawnego [w:] Przyszłość prawa pracy, red. Z. Hajn, D. Skupień, Liber Amicorum, WUŁ, Łódź 2015.

10. Romer M., Mobbing i jego konsekwencje, „Prawo Pracy”2005/12.

11. Schaub G., Rechte und Pflichten als Arbeitnehmer, Softcover, München 2001.

12. Semena J., Mobbing i przeciwdziałanie temu zjawisku na gruncie Kodeksu Pracy, „Kwartalnik Prawo-Społeczeństwo-Ekonomia” 2015/3.

13. Sobczyk A., Dörre-Nowak D., Przeciwdziałanie mobbingowi, „Monitor Prawa Pracy”, 2006/10, s. 523.

14. Szewczyk H., Zapobieganie mobbingowi oraz zwalczanie jego skutków przez pracodawcę, „Bezpieczeństwo Pracy”, 2015/10.

15. Tomaszewska M., Komentarz do art.94(3) Kodeksu pracy., teza nr 7.2. [w:] K.W. Baran Kodeks pracy. Komentarz, Wolters Kluwers, Warszawa 2016.

16. Wiese G., Der Persönlichkeitsschutz des Arbeitsnehmers gegenüber dem Arbeitgeber, "Zeitschrift für Arbeitsrecht”, 1971/1.

17. Wratny J., Kodeks pracy. Komentarz, C.H. Beck, Warszawa 2016. 


\title{
PRAWODAWSTWO
}

1. Ustawa z dnia 23 kwietnia 1964 r. Kodeks cywilny (tekst jedn.: Dz.U. z 2017 r., poz. 459 ze zm.).

2. Ustawa z dnia 26 czerwca 1974 r. Kodeks pracy (tekst jedn.: Dz.U. z 2016 r. poz. 1666 z późn. zm.).

\section{PSYCHOLOGICAL AND LEGAL ASPECTS OF MOBBING IN THE WORKPLACE}

\begin{abstract}
Violence in the workplace is a disturbing phenomenon that appears with an increasing and yet disturbing frequency. Mobbing is treated as an example of the pathology observed in the organization. The aim of the article is to present the psychological nature of the phenomenon of mobbing, as well as pointing to mobbing in the context of Polish labor law. The first part of the article is devoted to aspects related to the psychology of health and psychology of the organization. The second part of the article is devoted to the area of labor law. The first part of the article focuses on the psychological aspects of the phenomenon of mobbing. At the beginning, the definition of mobbing was approximated, and examples of violence behaviors observed in the organizational environment were also mentioned. The victim of mobbing and mobber was also characterized. Next is the place to discuss mobbing as a multi-stage process. The first part of the article closes the consequences of mobbing, which affect victim of violence, and organizational environment. The second part of the article is devoted to legal aspects of the phenomenon of workplace mobbing. The definition of mobbing in force in the Polish Labor Code was recalled. In addition, the employer's obligations imposed on him relative to victims experiencing violence in the workplace were also indicated. The article also includes a place, for examples, of preventive activities related to the prevention of mobbing in the organization. The article closes the legal consequences of mobbing.
\end{abstract}

Keywords: organizational pathology, violence in the organization, Polish labor law, anti-mobbing procedures.

DOI: $10.7862 /$ rz.2018.mmr.36

Tekst ztożono do redakcji: maj $2018 \mathrm{r}$.

Tekst przyjęto do druku: wrzesień 2018 r. 